\title{
Postharvest Dark Skin Spots in Potato Tubers Are an Oversuberization Response to Rhizoctonia solani Infection
}

\author{
Yossi Buskila, Leah Tsror (Lahkim), Michal Sharon, Paula Teper-Bamnolker, Orly Holczer-Erlich, \\ Shimon Warshavsky, Idit Ginzberg, Saul Burdman, and Dani Eshel
}

First, fourth, and ninth authors: Department of Postharvest Science, ARO, Volcani Center, Bet Dagan, Israel; second and fifth authors: Department of Plant Pathology and Weed Research, ARO, Gilat Research Center, Israel; third author: Department of Plant Science, The Faculty of Life Science, Tel-Aviv University, Israel; sixth author: Department of R\&D, Hevel Maon Enterprises, Negev, Israel; seventh author: Department of Plant Science, ARO, Volcani Center, Bet Dagan, Israel; eighth author: Department of Plant Pathology and Microbiology, The Robert H. Smith Faculty of Agriculture, Food and Environment, The Hebrew University of Jerusalem, Rehovot, Israel. Accepted for publication 9 November 2010.

\begin{abstract}
Buskila, Y., Tsror (Lahkim), L., Sharon, M., Teper-Bamnolker, P., Holczer-Erlich, O., Warshavsky, S., Ginzberg, I., Burdman, S., and Eshel, D. 2011. Postharvest dark skin spots in potato tubers are an oversuberization response to Rhizoctonia solani infection. Phytopathology 101:436-444.

Israeli farmers export 250,000 tons of potato tubers annually, $\approx 40,000$ tons of which are harvested early, before skin set. In recent years, there has been an increase in the occurrence of dark skin spots on earlyharvested potato tubers ('Nicola') packed in large bags containing peat to retain moisture. The irregular necrotic spots form during storage and overseas transport. Characterization of the conditions required for symptom development indicated that bag temperature after packing is 11 to $13^{\circ} \mathrm{C}$ and it reaches the target temperature $\left(8^{\circ} \mathrm{C}\right)$ only 25 days post-

ment of pathogen infection. Isolates from typical lesions were identified as Rhizoctonia spp., and Koch's postulates were completed with 25 isolates by artificial inoculation performed at 13 to $14^{\circ} \mathrm{C}$. Phylogenetic analysis, using the internal transcribed spacer sequences (ITS1 and ITS2) of rDNA genes, assigned three isolates to anastomosis group 3 of Rhizoctonia solani. Inoculation of wounded tubers with mycelium of these $R$. solani isolates resulted in an oversuberization response in the infected area. With isolate Rh17 of $R$. solani, expression of the suberin biosynthesis-related genes StKCS6 and CYP86A33 increased 6.8- and 3.4-fold, respectively, $24 \mathrm{~h}$ postinoculation, followed by a 2.9-fold increase in $P O P \_A, a$ gene associated with wound-induced suberization, expression $48 \mathrm{~h}$ postinoculation, compared with the noninoculated tubers. We suggest that postharvest dark spot disease is an oversuberization response to $R$. solani of AG-3 infection that occurs prior to tuber skin set.
\end{abstract} harvest. This slow decrease in temperature may promote the establish-
Potato (Solanum tuberosum L.) tubers are usually harvested after skin set and the curing process of harvest wounds is completed during the first 2 weeks of storage (32). During the curing process, native periderm forms a barrier to protect the tuber from dehydration and penetration of disease agents during storage $(34,43,45)$. In Israel, 'Nicola' potato tubers are harvested before skin set ("baby potatoes"), packed in large bags with humid peat to prevent water loss, and stored or exported overseas at $8^{\circ} \mathrm{C}$, before the curing process is complete. In recent years, there have been increasing reports of irregular, superficial necrotic spots developing during the first month after harvest on stored tubers. The phenomenon is so severe that, in some cases, it has led to almost total loss of potato shipments. Rhizoctonia spp. are frequently isolated from these necrotic lesions; however, artificial inoculation with Rhizoctonia isolates, to complete the Koch's postulates, did not give consistent results when performed at $25^{\circ} \mathrm{C}$ (unpublished data).

Rhizoctonia solani, a soil- and tuber-borne pathogen, can cause both quantitative and qualitative damage to potato crops (69). Quantitative losses occur due to infection of the stems, stolons, and roots, affecting tuber size and number $(12,51)$, whereas qualitative losses occur mainly through the production of misshapen

Corresponding author: D. Eshel; E-mail address: dani@agri.gov.il

*The $\boldsymbol{e}$-Xtra logo stands for "electronic extra" and indicates that Figures 1, 2, and 4 appear in color online.

doi:10.1094/PHYTO-09-10-0251

(c) 2011 The American Phytopathological Society tubers and the development of sclerotia on the tuber surface (27). Rhizoctonia disease of potato has been reported to cause up to $30 \%$ losses in marketable yield $(2,51,72)$.

The native potato periderm is characterized by three tissues: phellem, phelogen, and pheloderm (52). Suberin and waxes, embedded in the matrix, are considered essential for periderm imperviousness (20) and are localized between the primary wall and the plasmalemma (33). Cork (phellem cell) formation involves proliferation and cell expansion of the phellogen derivatives, extensive deposition of suberin and waxes, and an irreversible program of senescence ending in cell death. Suberin is composed of a hydroxycinnamic acid-monolignol poly(phenolic) domain, embedded in the primary cell wall, which is covalently linked to a glycerol-based poly(aliphatic) domain located between the primary cell wall and the plasma membrane $(5,47)$. Suberin is chemically similar to cutin but also contains an aromatic domain attached to its aliphatic polymeric domain $(6,20)$. The initial condensation step in the elongation of very-long-chain fatty acids (VLCFAs) is catalyzed by 3-ketoacyl-CoA synthase (KCS). This reaction is the rate-limiting step in fatty-acid elongation $(13,66)$. The aliphatic component of suberin is composed mainly from the monomers $\omega$-hydroxyacids and $\alpha, \omega$-diacids with chain lengths of C16 to C28 (mainly C18), together with glycerol (57). $\omega$ Hydroxylation of fatty acids is carried out in plants by cytochrome $\mathrm{P} 450$ monooxygenases $(C Y P)$. POP_A, an anionic peroxidase, has been shown to be both temporally and spatially associated with the wound-induced suberization process in potato tubers $(7,8,16,17)$. In the present study, we used histological methods and gene-expression analyses to demonstrate that post- 
harvest dark skin spots in potato tubers are caused by an oversuberization response to infection with $R$. solani. To the best of our knowledge, this is the first study to demonstrate damage to potato tubers caused by $R$. solani postharvest.

\section{MATERIALS AND METHODS}

Plant material and pathogen. Potato tubers ('Nicola') were grown in the northern Negev, Israel, under standard culture conditions and were harvested 90 to 95 days after planting, before skin set, in winter 2007 to 2009 . Tubers were stored at $8^{\circ} \mathrm{C}$ and $90 \%$ relative humidity, simulating commercial conditions. Stored tubers with spontaneous symptoms of dark skin spot were used to isolate the pathogen. Slices of diseased tissue $\left(1 \mathrm{~cm}^{2}\right)$ were surface-disinfected for $30 \mathrm{~s}$ in $80 \%$ ethanol, followed by treatment with $3 \%$ ( vol/vol) sodium hypochlorite for $2 \mathrm{~min}$, then rinsed three times in sterile water for $10 \mathrm{~s}$ and cut aseptically into two pieces. These were placed on sterile half-strength (wt/vol) potato dextrose agar (PDA) (Difco Laboratories, St. Louis) plates supplemented with chloramphenicol $(25 \mathrm{mg} / \mathrm{liter})$. The plates were incubated at $20^{\circ} \mathrm{C}$ and, after 3 days, single tips of fungal mycelium were transferred to sterile PDA. Several fungal species were identified by light microscopy and, in most cases, exhibited typical Rhizoctonia mycelia morphology. All isolated species were used in artificial inoculation tests (data not shown) (62). Rhizoctonia mycelia were stored at $4{ }^{\circ} \mathrm{C}$ and recultured every 2 months through reinoculation of the potato tuber to preserve pathogenicity. Five days before reinoculation, hyphae were transferred to a new plate at $25^{\circ} \mathrm{C}$ in the dark. Koch's postulates were conducted with 25 isolates, originating from several tubers representing three different fields. Isolate Rh17, used for the gene expression study (see below), represents colony number 17 of 25 $R$. solani colonies isolated from typical dark spot symptoms.

Potato tuber inoculation. Thirty tubers per treatment, in three replicates, were washed with tap water, surface-disinfected with $70 \%$ ethanol for $2 \mathrm{~min}$, and dried in a sterile laminar flow hood. Skin pieces ( 5 to $6 \mathrm{~mm}^{2}, 1$ to $2 \mathrm{~mm}$ thick) were excised from the tubers using a sterile scalpel, and 0.5-cm-diameter PDA disks containing 5-day-old fungus were placed on the exposed area. In control tubers, sterile PDA disks were placed on the skinless tissue. To investigate the deep parenchyma cells' response, we used disks sliced from the center part of five potato tubers per treatment. In three separate experiments, tuber disks were cut into 1-cm-thick slices and immediately placed on wet sterile filter paper in a petri dish before inoculation with the fungus.

Tuber storage and shipment simulation. Potato tubers were harvested and packed using standard commercial procedures in 1.25 -ton bags made of woven polypropylene. The tubers were mixed with wet peat ( $60 \%$ water content) at a ratio of 150 to 200 liters of peat per bag and were stored at $8^{\circ} \mathrm{C}$ and $90 \%$ relative humidity. Temperature sensors, connected to a data logger (CR10; Campbell Scientific Ltd., Logan, UT), were placed in the bags at four heights (every $50 \mathrm{~cm}$ ) (Fig. 1). Silicon air tubes $(1 \mathrm{~cm}$ in diameter) were placed next to each sensor to sample the air inside the bag. Levels of $\mathrm{CO}_{2}$ were determined once a week by gas chromatography using a thermal conductivity detector (Series 580; GOW-MAC Instruments Co., Bethlehem, PA). At the end of the storage period (30 days), bags were unloaded by hand and the number of tubers with dark skin spots was estimated visually. Changes in peat water content were determined by measuring the weight loss after oven drying 100 -g samples at $70^{\circ} \mathrm{C}$ for $48 \mathrm{~h}$.

Fungal DNA extraction. Mycelia of Rhizoctonia spp. isolated from typical lesions were grown in potato dextrose broth supplemented with chloramphenicol (PDBcm) at $250 \mu \mathrm{g} / \mathrm{ml}$ for 10 days. Tissue samples were collected by vacuum filtration in three replicates and lyophilized to dryness. DNA was extracted and purified as described previously (54). The obtained DNA was suspended in $0.5 \mathrm{ml}$ of Tris-EDTA buffer $(10 \mathrm{mM}$ Tris- $\mathrm{HCl}$, $1 \mathrm{mM}$ EDTA, $\mathrm{pH}$ 8.0) and stored at $4^{\circ} \mathrm{C}$ until use.

Sequencing of rDNA internal transcribed spacer. The rDNA internal transcribed spacer (ITS) fragment (ribosomal ITS1, ITS2, and 5.8S gene) was amplified using primers ITS4 (5'-TCC TCCGCTTATTGATATGC-3') and ITS5 (5'-GGAAGTAAAA GTCGTAACAAGG-3') (74). The reaction mixture was prepared as described by Freeman et al. (21). The polymerase chain reaction (PCR) program was as follows: 5 min of denaturation at $95^{\circ} \mathrm{C}$; followed by 40 cycles of $30 \mathrm{~s}$ at $95^{\circ} \mathrm{C}, 30 \mathrm{~s}$ at $50^{\circ} \mathrm{C}$, and $90 \mathrm{~s}$ at $72^{\circ} \mathrm{C}$; and termination at $72^{\circ} \mathrm{C}$ for $10 \mathrm{~min}$. PCR-amplified rDNA-ITS products were extracted from $1 \%$ agarose gels using a DNA isolation kit (Biological Industries, Beit Ha'emek, Israel).
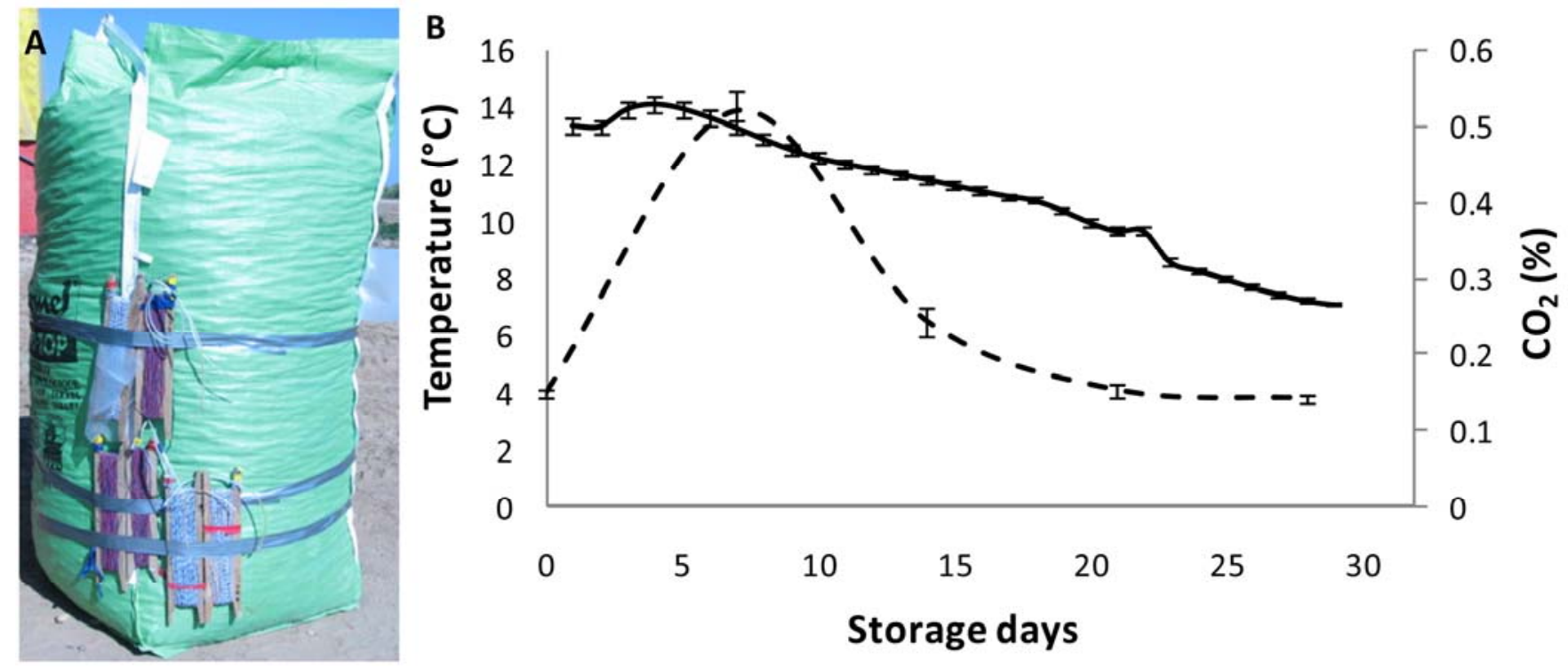

Fig. 1. Temperature and $\mathrm{CO}_{2}$ levels during storage of 'Nicola' potato tubers, immediately after harvest. A, Packed commercial "big bag" (1.25-ton bags made of woven polypropylene). Tubers were mixed with wet peat ( $60 \%$ water content) at a ratio of 150 to 250 liters of peat per bag and were stored at $8{ }^{\circ} \mathrm{C}$ and $90 \%$ relative humidity. Temperature sensors, connected to a data logger, were placed in the bags at four heights (every $50 \mathrm{~cm}$ ). Silicon air tubes (1 cm in diameter) were placed next to each sensor to sample the air inside the bag. $\mathbf{B}$, Temperature (solid line) is represented by daily average of measurements taken every 20 min; $\mathrm{CO}_{2}$ levels (dashed line) were measured every 7 days at four heights. Each time point (temperature or $\mathrm{CO}_{2}$ ) represents an average of measurements taken at four heights in four bags and bars represent the standard error. 
Ligation and cloning into competent cells of Escherichia coli DS5 (60) were performed with the pGEM-T Easy Vector System Kit (Promega Corp., Madison, WI). Plasmids were extracted with the Wizard Plus Sv Minipreps DNA-Purification System (Promega Corp.). The Big Dye Terminator DNA Sequencing Kit (Applied Biosystems, Foster City, CA) was used to determine the sequence of the amplicon (ITS regions 1 and 2, including the 5.8S rDNA gene), using vector primers SP6 and T7 (74), by Hylabs Ltd. (Rehovot, Israel).

Similarity and cluster analyses of the rDNA-ITS region of Rhizoctonia spp. Three different isolates were used for the ITS sequence analysis (representing the three fields); results were similar and, therefore, those from isolate Rh17 are presented here. $R$. solani is grouped into 13 anastomosis groups (AGs). AG-3 is divided into two main subgroups, PT and TB, originating from potato and tobacco, respectively $(11,29,35)$. The sequences of our isolate (Rh17, accession number HQ444263) and those available from GenBank (accession numbers AB000001, AY154319, and AB000004 for the TB subgroup; AB000042, AB019023, and AB019017 for the PT subgroup; and AY684917 as an outgroup) (35-37) were processed and refined, before alignment, using Chromas version 1.45 (http://www.trishul.gu.edu.au/nconor/ chromas). Processed sequences were submitted to ClustalW in the DNA Data Bank of Japan (DDBJ), Research Organization of Information and Systems, National Institute of Genetics, Shizuoka, Japan http://www.ddbj.nig.ac.jp) for multiple alignments. The results were analyzed by Genedoc version 2.5.000 (48). Manual alignment corrections were performed when necessary. Similarity and identity levels of the compared sequences were calculated with the MatGat program (10). Cluster analysis was performed using the similarity analysis results in a neighborjoining (NJ) method in the DDBJ and viewed by Tree View version 1.6.6 (49). The distances in the phylogenetic tree were determined according to Kimura's two-parameter model (31). Bootstrap analysis using 100 resamples of the sequence data was carried out. Bootstrap values were calculated with the Seqboot program. Seqboot, Dnapars, and Consense were all from the Phylip Package 3.6 (18). Bootstrap values $>60$ are presented.

Tissue embedding and histological staining. For the histological work, we sampled tissue from the whole tuber and tuber disks as described above. Analyses of periderm formation and morphology were performed under a light and UV microscope (Leica DMLB; Leica Microsystems, Bensheim, Germany). Images were displayed on a monitor through a Leica CCD DC2000 camera using the IM1000 program (Leica Microsystems, Heerbrugg, Switzerland). The same samples were viewed under UV light to detect autofluorescence of suberized cell walls in the skin. The DMLB microscope was configured for epifluorescent illumination using an HBO103W/2 mercury lamp, excitation filter BP 340-380, chromatic beam-splitter FT 400, and barrier filter LP 425. For periderm-formation analyses, $10-\mathrm{mm}^{2}$ samples of inoculated and noninoculated wounded tissue were fixed in FAA (10\% formaldehyde, $5 \%$ acetic acid, and $50 \%$ ethanol [ $\mathrm{vol} / \mathrm{vol}]$ ), dehydrated in an ethanol-Histoclear (National Diagnostics, Atlanta) series, and embedded in Paraplast (Paraplast Plus; Oxford Labware, St. Louis) according to standard methods (55). Tissue sections were cut to 20 -mm thickness using a rotary microtome 820 (American Optical Co., Buffalo, NY). Sections were dried at $42^{\circ} \mathrm{C}$ for $36 \mathrm{~h}$ and then stained with Safranin O/Fast green (Sigma-Aldrich, Rehovot, Israel) for examination of tissue morphology (28) and glued (onto the slide) with Entellan New (Merck, Darmstadt, Germany). Formation of suberized tissue was monitored in live sections; tissue was embedded in $6 \%(\mathrm{wt} / \mathrm{vol})$ low-melting agarose, solidified, and then cut with a VT 1000 Vibratom (Leica Microsystems). Sections were stained with Sudan IV (Sigma-Aldrich) (23), which binds to fatty acids in the polyaromatic component of suberin (5).

Potato RNA isolation. Potato periderm tissue samples were collected using a scalpel blade from inoculated and control tubers at several stages: immediately after wounding (time 0) and 4, 24, 48 , and $72 \mathrm{~h}$ post wounding. Tissue samples were collected from five independent infected and control tubers at each time point and immediately frozen in liquid $\mathrm{N}_{2}$ and stored at $-80^{\circ} \mathrm{C}$ until use. Total RNA was isolated according to Meisel et al. (46). Briefly, the tissue was ground in liquid $\mathrm{N}_{2}$ with an A11 electrical grinder (IKA, ScienceLab, Houston) and $2 \mathrm{~g}$ of powdered tissue was transferred to a 15-ml centrifuge tube containing $6 \mathrm{ml}$ of preheated extraction buffer treated with diethyl pyrocarbonate. Extraction buffer (cetyltrimethylammonium bromide) preparation and procedure were as described by Meisel et al. (46). After extraction, RNA samples were treated with Turbo DNase (Ambion, Austin, TX) to remove contaminating DNA according to the manufacturer's protocol. Concentrations of RNA samples were measured with a ND-1000 spectrophotometer (Nanodrop Technologies, Rockland, DE) and purity was verified by optical density absorption ratio at 260 and $280 \mathrm{~nm}\left(\mathrm{OD}_{260} / \mathrm{OD}_{280}\right)$ of 1.80 to 2.05 and $\mathrm{OD}_{260} / \mathrm{OD}_{280}$ of 2.00 to 2.30 . Sample integrity was evaluated by electrophoresis on $1 \%$ agarose gels (Lonza, Rockland, ME) containing Safe-View Nucleic Acid Stain (NBS Biologicals, Huntingdon, UK) at $0.5 \mu \mathrm{g} / \mathrm{ml}$. Observation of intact $18 \mathrm{~S}$ and $28 \mathrm{~S}$ rRNA subunits and absence of smears in the gel indicated minimal RNA degradation.

cDNA synthesis and mRNA expression analyses. StKCS6, $C Y P 86 A 33$, and $P O P \_A$, suberization-related genes were targets for an expression analysis study. cDNA was synthesized from $1 \mu \mathrm{g}$ of total potato RNA using the Verso cDNA Kit (ABgene, Surrey, UK), that contain random hexamers and anchored oligodT 3:1 (vol/vol), according to the manufacturer's specifications. Because the sequences of the target genes were based on previous research with 'Désirée' and 'White Rose' potato $(53,58,59)$, primers were designed to amplify each of the target genes from 'Nicola', based on the published sequences (Table 1). PCR products obtained from 'Nicola' were than sequenced to design specific quantitative real-time reverse-transcription (RT)-PCR primers for this cultivar. PCR was performed with ReddyMix (ABgene) for 36 cycles of denaturation at $95^{\circ} \mathrm{C}$ for $10 \mathrm{~s}$, annealing under a

TABLE 1. Primers used for cDNA synthesis and quantitative real-time polymerase chain reaction (PCR)

\begin{tabular}{|c|c|c|c|c|}
\hline Accession $^{\mathrm{a}}$ & Reaction $^{\mathrm{b}}$ & Gene name & Reverse primer $\left(5^{\prime} \rightarrow 3^{\prime}\right)$ & Forward primer $\left(5^{\prime} \rightarrow 3^{\prime}\right)$ \\
\hline \multirow[t]{2}{*}{ X67238 } & RT-PCR & $18 S$ & GCCATCCCAAAGTCCAACTA & AAACGGCTACCACATCCAAG \\
\hline & qRT-PCR & $18 S$ & TTGCCCTCCAATGGATCCTCGTTA & AATTACCCAATCCTGACACGGG \\
\hline \multirow[t]{2}{*}{ EU616538 } & RT-PCR & StKCS5 & TCCTTTCGCCTCGATGTAAC & TGGGTGGTGCTGCTATACTTT \\
\hline & qRT-PCR & StKCS5 & AACAGCTCTTCCACCAGCATG & CCAGCATCAGAGCAGCTTCTT \\
\hline \multirow[t]{2}{*}{ EU293405 } & RT-PCR & Сур $86 A 33$ & TTTGGTGAAAGGGTTTCAGG & TCTACTGGGGTATCCGCAAC \\
\hline & qRT-PCR & Сур $86 A 33$ & GCAACTCGACCGGGTTTTTT & GGTGGGTAAACCGGACCATC \\
\hline \multirow[t]{2}{*}{ M21334 } & RT-PCR & $P O P \_A$ & GCATCAACTGATCATAATACTGAAAG & GGATCAAGTTTTGACCGGGGATG \\
\hline & qRT-PCR & POP_A & CCCTGCTACAAACATCACGA & TTGCTGCTGCCATGATCA \\
\hline
\end{tabular}

\footnotetext{
a GenBank accession numbers.

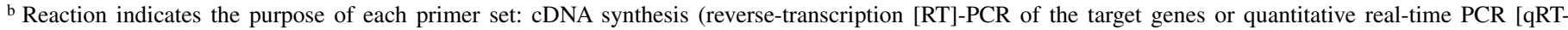
PCR]). RT-PCR primers were designed, based on published sequences, to obtain cDNA clones of each target gene from 'Nicola' potato. Amplified cDNA clones were then used to design specific primers with Primer Express2.0 (Applied Biosystems) for qRT-PCR.
} 
temperature gradient of 55 to $62^{\circ} \mathrm{C}$ for $30 \mathrm{~s}$, and extension at $72^{\circ} \mathrm{C}$ for $1 \mathrm{~min}$, followed by a final extension step of $10 \mathrm{~min}$ at $72^{\circ} \mathrm{C}$. Sequences were clustered using BioEdit Sequence Alignment Editor Software (http://www.mbio.ncsu.edu/BioEdit/ bioedit.html). The sequences with the longest perfect repetitions and flanking regions that permitted primer design were selected for real-time PCR primer design (Table 1), using Primer Express 2.0 (Applied Biosystems).

RNA analysis. Quantitative real-time RT-PCR analysis of potato cDNA was performed using the ABsolute QPCR SYBR Green Mix kit (ABgene, Epsom). Reactions were run on a Corbett Research Rotor-Gene 3000 cycler (Corbett Research, Mortlake, Australia). To check for DNA contamination, we ran a reaction with RNA only. Primers were designed with Primer Express 2.0 (Applied Biosystems) and synthesized by SigmaAldrich. Primer sequences are given in Table $1.18 S$ was used as a housekeeping gene (15). A standard curve was obtained for each gene using the fragment containing its amplified region. Reactions for each gene in each cDNA sample were repeated independently at least four times, and gene quantification was performed using Corbett Research Rotor-Gene software. We only used replicates in which the standard deviation of a population was $<1.5 \%$ of the average. Relative expression of a gene in a particular sample was obtained by dividing the gene expression level by the $18 S$ level (in arbitrary units).

\section{RESULTS}

Assessment of environmental conditions associated with formation of dark spots. Initial attempts to induce formation of dark spot symptoms following inoculation of tubers with $R$. solani isolated from symptomatic tubers were not consistently successful. Therefore, we set out to determine the environmental conditions that could be associated with the development of these symptoms, so as to optimize the conditions for artificial inoculation. Specifically, we followed the changes in temperature and $\mathrm{CO}_{2}$ concentration during storage in four commercial 1.25-ton potato bags (Fig. 1). The initial temperature (after harvest) in the tuber bags was 12 to $13^{\circ} \mathrm{C}$, and it increased to $14^{\circ} \mathrm{C}$ during the first week of storage. The bags only reached their target temperature $\left(8^{\circ} \mathrm{C}\right)$ after 25 days of storage (Fig. 1B). The $\mathrm{CO}_{2}$ concentration in the air surrounding the tubers rose from $0.15 \%$ at the beginning of storage to $0.55 \%$ after the first week of storage. Thereafter, $\mathrm{CO}_{2}$ concentration began to decrease, approximating its initial level after only 3 weeks (Fig. 1B). The water content in the peat surrounding the tubers started at $60 \%$ and decreased to $25 \%$ by the end of 1 month of storage (data not shown).

Inoculation of potato tubers with $\boldsymbol{R}$. solani. Simulation of the temperature, humidity, and aeration conditions determined in the commercial bags enabled us to complete Koch's postulates by artificial inoculation. In most cases, dark spots spontaneously appearing during commercial storage of 'Nicola' potato tubers (Fig. 2A) were used for Rhizoctonia spp. isolation. Wounded, noninoculated control tubers placed in humidified peat at 13 to $14^{\circ} \mathrm{C}$ for 2 to 3 weeks developed new skin without formation of necrotic symptoms (Fig. 2B). Healthy tubers were wounded and inoculated with several fungal species isolated from the dark spots (e.g., Fusarium, Trichoderma, and Phytophthora spp.). Typical superficial necrotic spots were induced only in tubers inoculated with isolates that showed morphological features of Rhizoctonia spp. (50) (Fig. 2C). The hyphae reisolated from the necrotic spots had $R$. solani characteristics: T-shaped cells, location of the septum, formation of barrel cells, production of sclerotia, and brown pigmentation of the hyphae were observed, as described by Parmeter and Whitney (50) (data not shown). Necrotic symptoms induced by these isolates occurred in $\approx 85 \%$ of the inoculated tubers, and the observed symptoms were similar, although more concentrated.

Characterization of Rhizoctonia isolates by determination of AG. To verify that the fungus causing dark spot symptoms indeed belongs to the genus Rhizoctonia and to further identify its species, AG, and subgroup, we used ITS sequence comparison. Previous studies have shown division of the $R$. solani phylogenetic tree into AGs (61). Sequence preliminary analysis of the ITS of three isolates showed high identity between them and revealed that they belong to the AG-3 group of $R$. solani. Further comparative analysis was performed between the Rh17 ITS sequence and sequences from other AG-3 isolates available in GenBank (Table 2). AG-3 is divided into two main subgroups, PT and $\mathrm{TB}$, originating from potato and tobacco, respectively $(29,35)$. Similarity and identity levels of the compared sequences (calculated with the MatGat program [10] and summarized in Table 2) indicated that Rh17 belongs to the subgroup PT within AG-3: whereas the minimum and maximum identity scores of Rh17 to the isolates of the PT subgroup were 98.9 and $99.4 \%$,

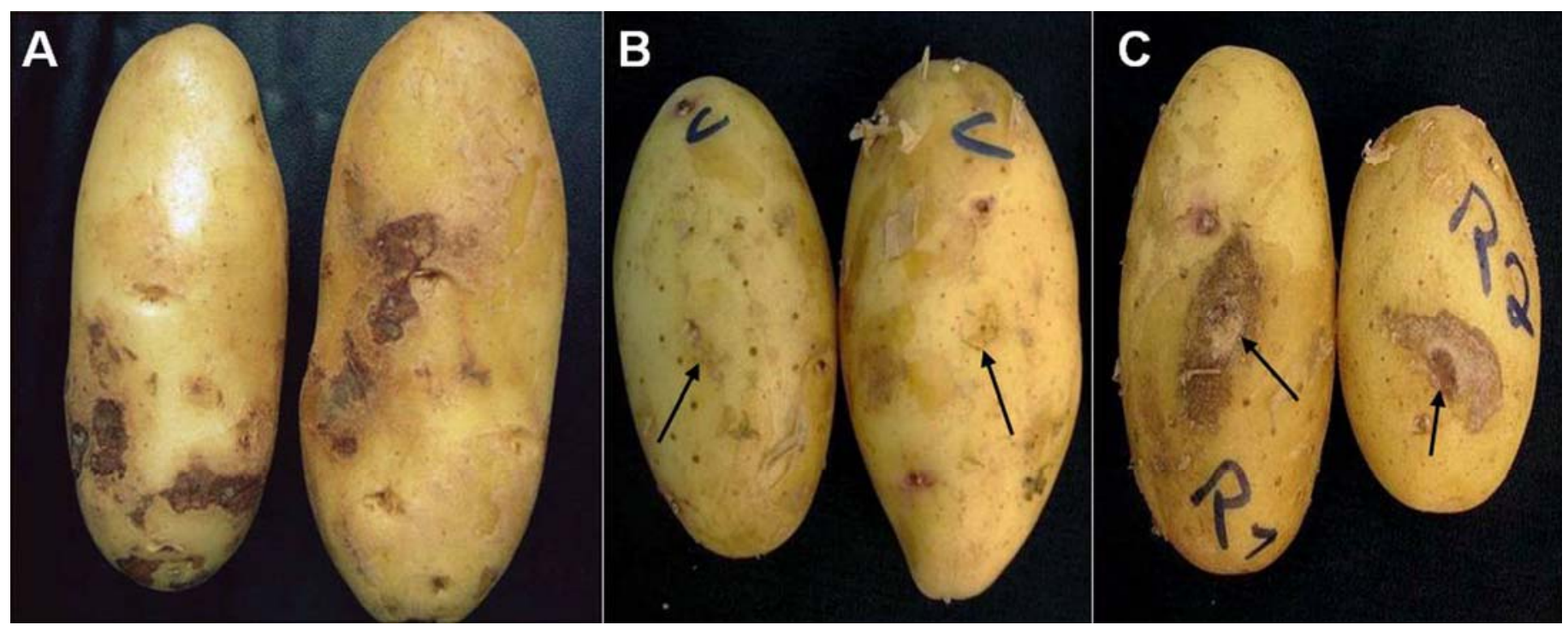

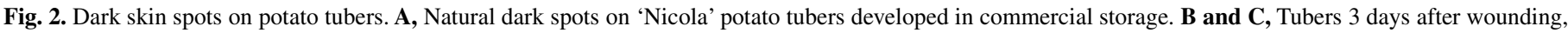

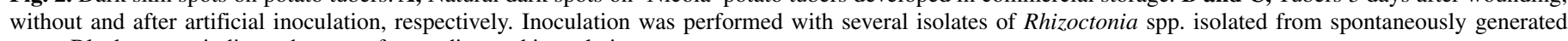
spots. Black arrows indicate the area of wounding and inoculation. 
respectively, the identity score of Rh17 to the isolates of the TB subgroup was only $95.1 \%$. An NJ tree based on ITS sequences from representative $R$. solani AG-3 isolates clearly supported the finding that Rh17 belongs to the PT subgroup (Fig. 3).

Tuber cortex and deeper parenchyma cells' response to $R$. solani inoculation. Artificial inoculation of potato tubers with isolate Rh17 and with other isolates from a typical dark spot induced a thicker closing layer with oversuberization of the cell walls compared with wounded, noninoculated controls. Inoculation was performed immediately after removing the tuber's native periderm with a scalpel blade (Fig. 4A). In the control (wounded only) sections, 5 days after wounding, periderm initials began to form underneath the closing layer (Fig. 4B), whereas the inoculated tissue formed a thicker and less organized layer (Fig. 4C). Sudan IV staining of live sections of the wounded, noninoculated area 10 days after wounding revealed suberized periderm with an average of six \pm two cell layers organized in characteristic cell columns (Fig. 4D). These cells showed pronounced blue autofluorescence (Fig. 4E) when exposed to UV light (365 nm). Inoculation with $R$. solani increased the number of cells in the closing layer but the number of periderm cell layers remained, on average, six \pm two (Fig. $4 \mathrm{~F}$ and $\mathrm{G}$ ). The closing layer contained bigger and more suberized cells (Fig. 4D to G). A similar phenomenon was observed in the tuber's deeper parenchyma tissue upon inoculation with $R$. solani (Fig. $4 \mathrm{H}$ and I). The pathogen induced a thicker closing layer with oversuberized cell walls (Fig. 4I) than the noninoculated control (Fig. $4 \mathrm{H}$ ). As expected, the closing layers formed in both cases (cortex and deeper parenchyma) were less compact and organized than the phellem cells in the natural skin of nontreated tubers (Fig. 4J). It appears that the closing layer that develops without inoculation is thin and unstable and, therefore, cannot maintain its original shape under the hand-dissection performed here with live tissue (Fig. 4D and E). This layer is thicker and likely more stable in inoculated tubers, probably as a result of the induced oversuberization (Fig. 4F and G). For the fixed tissues, we used a microtome for dissection, likely enabling preservation of this layer's shape (Fig. 4B and H).

Expression of suberin biosynthesis-related genes. To further verify that $R$. solani infection induces oversuberization in the tuber cell walls, we assessed the expression of potato genes StKCS6, CYP86A33, and POP_A, encoding enzymes which have been reported to be involved in suberin biosynthesis (5). Indeed, the assessed genes were found to be more highly expressed in response to $R$. solani inoculation. Expression of StKCS6 and CYP86A33 increased 6.8- and 3.4-fold, respectively, $24 \mathrm{~h}$ after

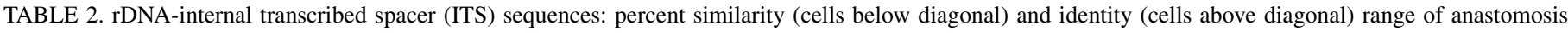
group 3 subgroups TB and PT, originating from potato and tobacco, respectively $(29,35)$, based on nucleotide sequence ${ }^{\mathrm{a}}$

\begin{tabular}{|c|c|c|c|c|c|c|c|c|c|}
\hline \multirow[b]{2}{*}{ GenBank accession no. } & \multirow[b]{2}{*}{ Subgroup } & \multicolumn{8}{|c|}{ Identity (similarity) } \\
\hline & & 1 & 2 & 3 & 4 & 5 & 6 & 7 & 8 \\
\hline 1. $\mathrm{AB} 000001$ & TB & $\ldots$ & 100 & 100 & 94.8 & 95.1 & 95.4 & 94.9 & 61.7 \\
\hline 2. AY154319 & TB & 100 & $\ldots$ & 100 & 94.8 & 95.1 & 95.4 & 94.9 & 61.7 \\
\hline 3. $\mathrm{AB} 000004$ & TB & 100 & 100 & $\ldots$ & 94.8 & 95.1 & 95.4 & 94.9 & 61.7 \\
\hline 4. $\mathrm{AB} 000042$ & PT & 94.9 & 94.9 & 94.9 & $\ldots$ & 99.4 & 98.3 & 98.9 & 63.1 \\
\hline 5. Rh17 & $\ldots$ & 95.2 & 95.2 & 95.2 & 99.4 & $\ldots$ & 98.3 & 98.9 & 63.4 \\
\hline 6. $\mathrm{AB} 019023$ & PT & 95.4 & 95.4 & 95.4 & 98.3 & 98.3 & $\ldots$ & 98.1 & 62.9 \\
\hline 7. $\mathrm{AB} 019017$ & PT & 95.2 & 95.2 & 95.2 & 98.9 & 98.9 & 98.1 & $\ldots$ & 63.3 \\
\hline 8. AY684917 & Out group & 65 & 65 & 65 & 66.9 & 67.3 & 66.9 & 67.3 & $\ldots$ \\
\hline
\end{tabular}

${ }^{a}$ Rhizoctonia isolate from this study: Rh17. Isolate AY684917 (Athelia (Sclerotium) rolfsii) was used as the outgroup.

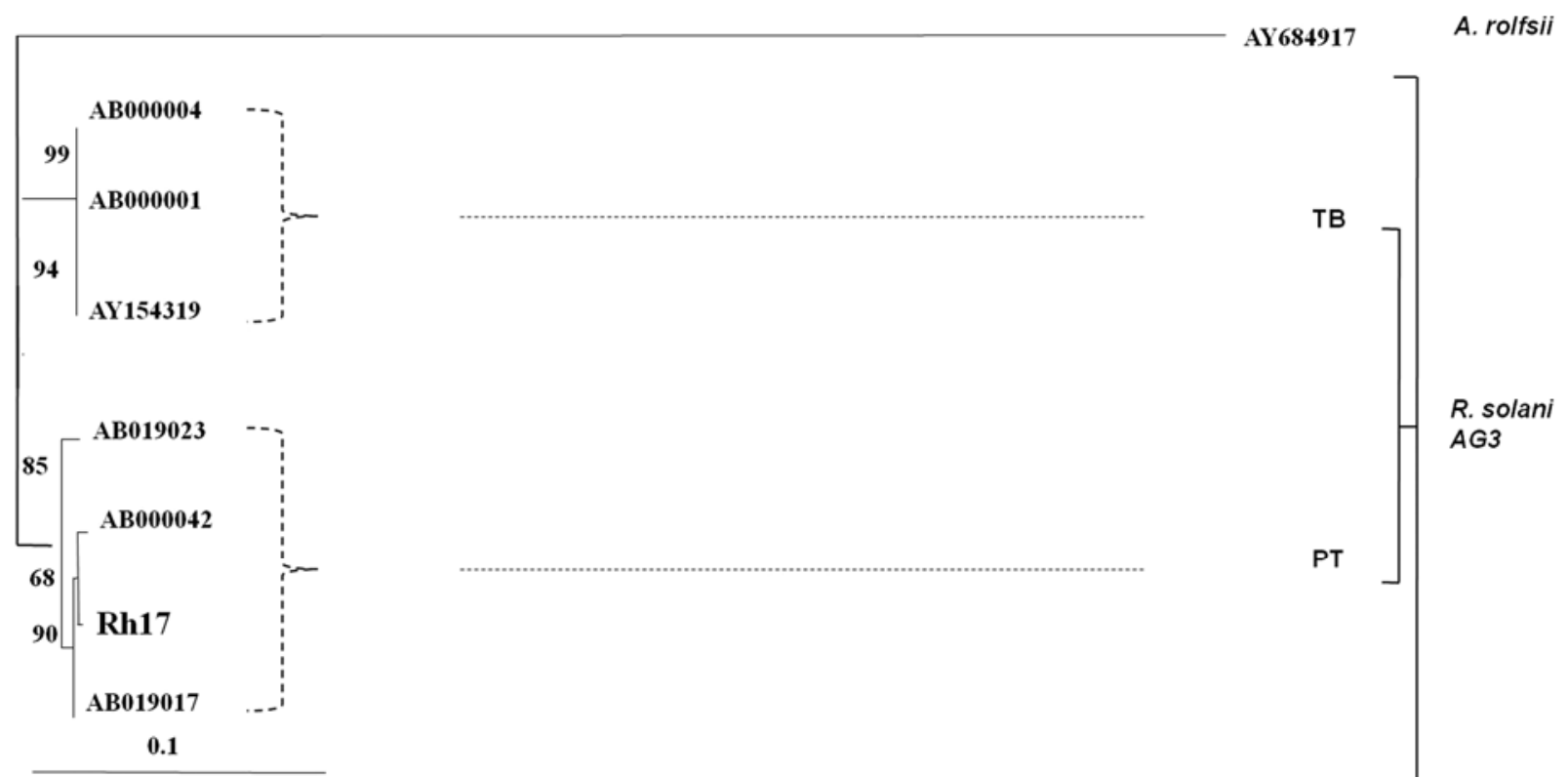

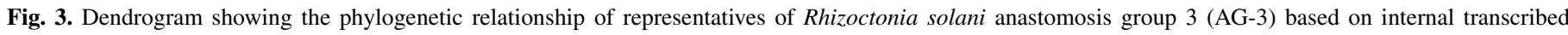

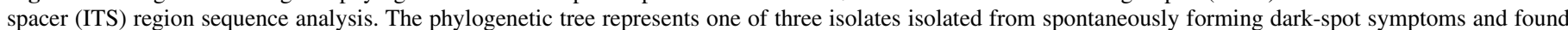

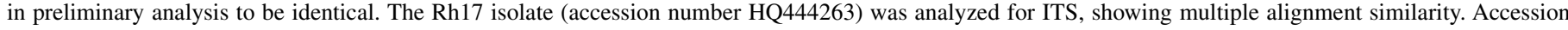

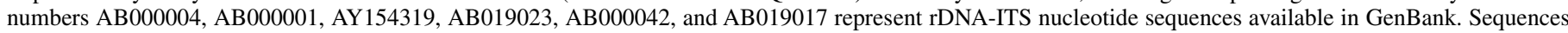

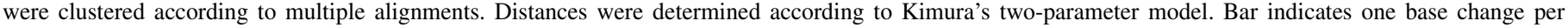

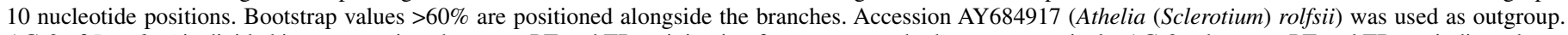
AG-3 of $R$. solani is divided into two main subgroups, PT and TB, originating from potato and tobacco, respectively. AG-3 subgroups PT and TB are indicated. 
inoculation with $R$. solani $\mathrm{Rh} 17$ relative to noninoculated controls (Fig. 5A and B). This was followed by a 2.9 -fold increase in the expression of POP_A $48 \mathrm{~h}$ after inoculation compared with noninoculated controls. All three genes were highly expressed for a single time point $(24$ or $48 \mathrm{~h})$, returning to basal levels for StKCS6 and CYP86A33 or reduced expression levels for POP_A (Fig. 5A to C).

\section{DISCUSSION}

$R$. solani is known as a soil- and tuber-borne pathogen of potato that causes stem canker, stolon pruning, and black scurf on tubers by forming sclerotia on the tuber skin $(1,56,69)$. However, to the best of our knowledge, this is the first report describing $R$. solani as a postharvest pathogen of potato. The practice of harvesting
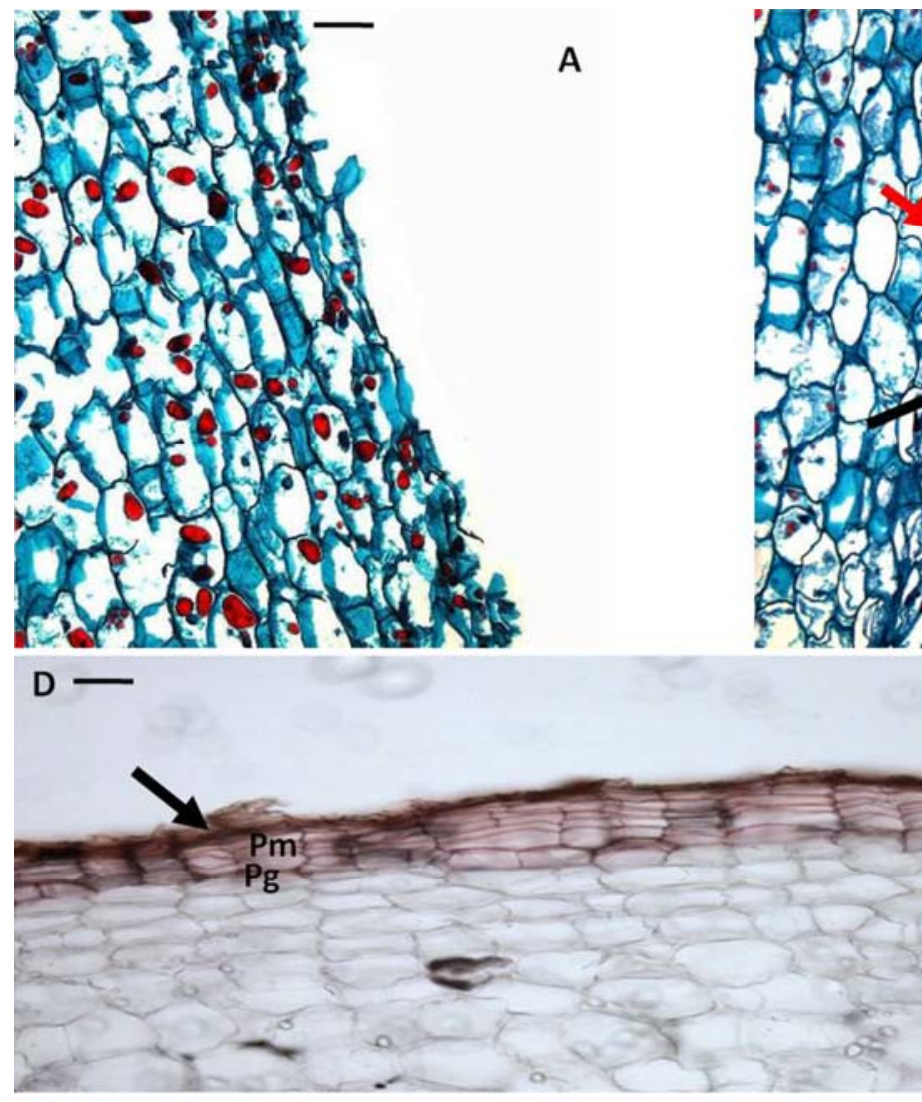

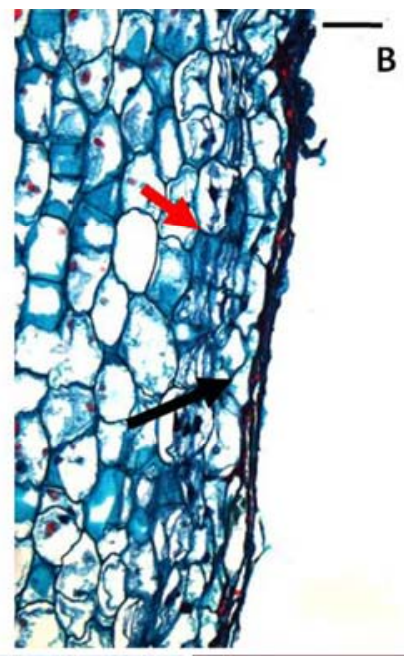

B
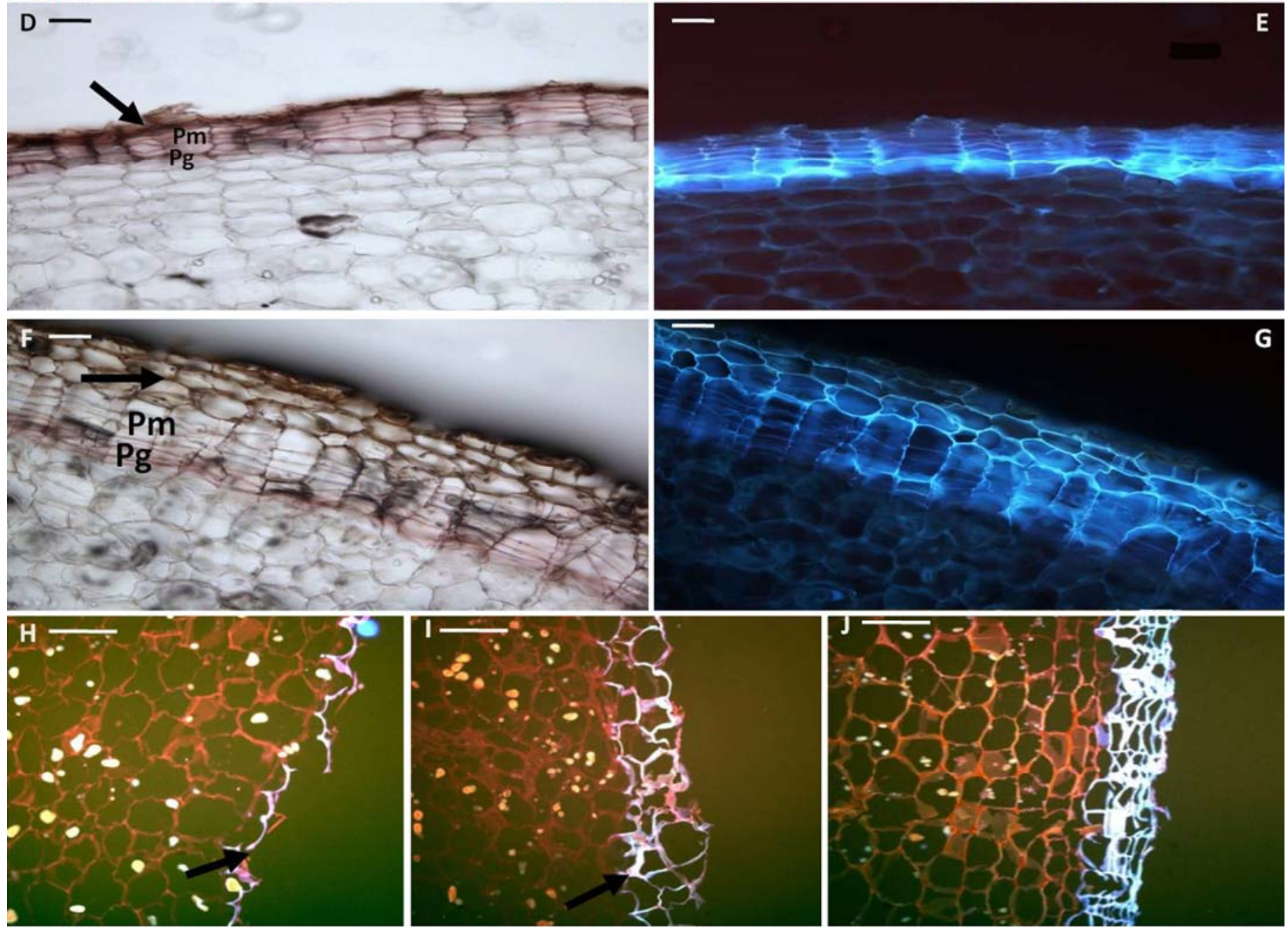

Fig. 4. Histological sections of 'Nicola' tuber inoculated with $R$. solani. A, B, and C, Paraffin-embedded sections stained with Safranin O/Fast green of tissue samples taken immediately after wounding, or 5 days after wounding without or following inoculation, respectively. D to G, Live sections of periderm tissue 10 days after wounding $\mathbf{D}$ and $\mathbf{E}$, without or $\mathbf{F}$ and $\mathbf{G}$, following inoculation. Sections were stained with Sudan IV and viewed under visible (D and F) or UV (E and G) light. Pm, phellem layer; Pg, phelogen layer. $\mathbf{H}$ and I, Paraffin-embedded sections of deep parenchyma tissue 3 days after slicing (control) and in inoculated disks, respectively, viewed under UV light. J, Embedded section of native potato periderm under UV light. Black arrows indicate closing layer or periderm initials. Scale bar $=100 \mu \mathrm{m}$. 
potato tubers before skin set probably leads to the production of more wounds during mechanical harvesting. The poor ventilation in commercial packaging bags, along with enhanced respiration of the tubers as reflected by the elevated levels of $\mathrm{CO}_{2}$ observed in our study, likely slows the cooling process compared with standard conditions. In our experiments, under commercial storage conditions, the tubers only reached the target storage temperature of $8^{\circ} \mathrm{C}$ after 25 days in storage; during the first week of storage, the temperature was 12 to $14^{\circ} \mathrm{C}$. We hypothesized that this could be enough time for the fungus to become established
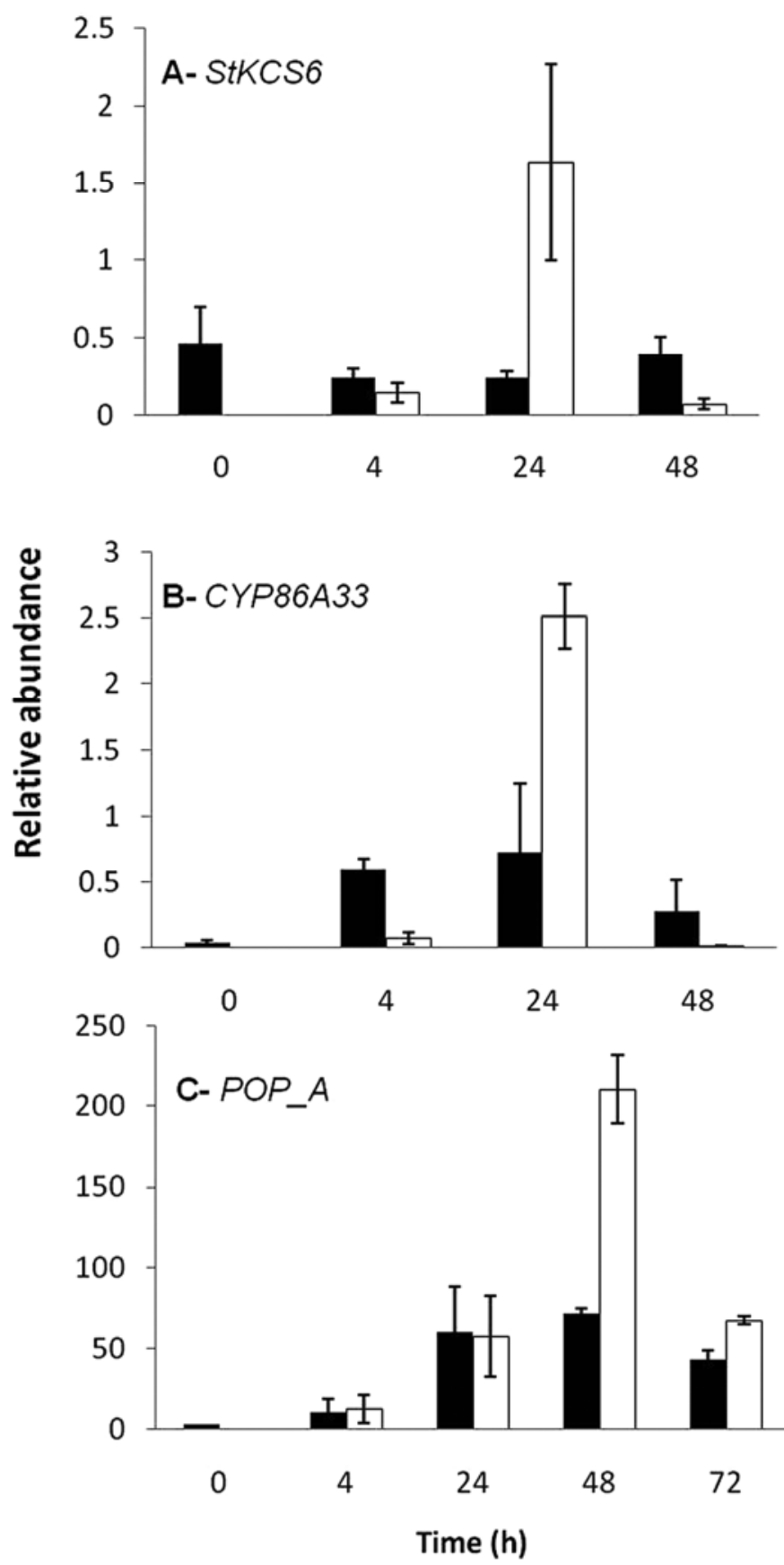

Fig. 5. Upregulation of suberin-related genes following inoculation of potato tubers with Rhizoctonia solani isolate Rh17. Samples were collected from wounded noninfected tuber tissues (black bars) or wounded tuber tissues inoculated with Rh17 (white bars) at the specified times post wounding. Expression levels of $\mathbf{A}$, StKCS6; $\mathbf{B}, C Y P 86 A 33$; and $\mathbf{C}, P O P \_A$ were determined by quantitative real-time reverse-transcription polymerase chain reaction analysis. Values were normalized to the housekeeping gene $18 S$. Data present the average of three experiments. Error bar represents standard error between tissue samples in the three experiments. and induce the oversuberization symptom. Indeed, in support of this hypothesis, these environmental conditions promoted $R$. solani infection of tubers in the laboratory, leading to the formation of dark spots similar to those observed in commercial storage, 3 days after inoculation. Importantly, the experiments in which we followed temperature changes in commercial storage bags were performed during the winter season in Israel. It is logical to expect that the initial temperature of the tubers in the early summer-the second harvesting season in Israel-is higher than in winter and, therefore, the cooling period in the summer could be even longer, thus promoting a higher occurrence of dark spot disease. On the other hand, in the summer, potato tubers are harvested only after skin set, which probably prevents the phenomenon from being more problematic.

Classification of Rhizoctonia spp. is first based on characterization of the cell's nuclear condition (multinucleate, binucleate, or uninucleate) and the ability of hyphae to anastomose with tester isolates of designated AGs (64). Presently, 13 AGs are known (11). The ITS regions (ITS1 and ITS2) flanking the 5.8S subunit have been very useful for evaluating phylogenetic and taxonomic relationships and for determining genetic diversity in fungal species $(9,40,61)$. Here, using ITS sequence analysis, we were able to assign the causal agent of dark spot symptoms to AG-3 of $R$. solani. Several AGs of $R$. solani are able to infect potato (3) but some are limited in their ability to infect different parts of the plant. AG-3 can be further divided into two subgroups (PT and TB), which are genetically distinct and differ in cultural appearance, fatty-acid profile, and pathogenicity $(29,35)$. PT is usually associated with potato and TB is generally associated with tobacco. In agreement with this, the potato dark spot isolate characterized in our study was demonstrated to belong to the PT subgroup of AG-3 (Table 2; Fig. 3).

The potato skin contains suberized phellem cells in the outer layer of the tuber periderm. Wound-induced deposition of suberin phenolics is a relatively slow process, which reaches maximum levels after 5 to 10 days (25). Previous work has shown that biotic and abiotic stresses can induce oversuberization of potato skin periderm cells (25). Lulai and Corsini (42) showed that Erwinia carotovora and Fusarium sambucinum infections are greatly enhanced when suberization is inhibited. Thomas et al. (67) demonstrated partial resistance to Phytophthora sojae due to a higher amount of suberin in soybean root. Lulai (41) showed induction of suberin in potato tuber parenchyma cells in response to the wilt disease pathogen Verticillium dahlia. In the phenomenon known as tuber pink eye, the absence of suberized cells in the native periderm results in tissue that is not protected against $R$. solani penetration; however, formation of a new pellogen and periderm layer under the closing layer blocks hyphal penetration to deeper tissue (44). In the present study, we showed that $R$. solani induces an oversuberization response in the closing layer and in the periderm that is strongly associated with the formation of superficial dark skin spots (Fig. 4). Oversuberization was observed when we inoculated the cortex layer, simulating superficial harvest wounds, and in the deeper parenchyma tissue as well (Fig. 4).

StKCS6 and CYP86A33, which are involved in the synthesis of suberin polyaliphatic domain, exhibited the highest expression level in the infected area $24 \mathrm{~h}$ after inoculation. This correlated with the observed oversuberization 5 days after inoculation as expressed by a thicker closing layer. The expression in StKCS6 leads to accumulation of VLCFAs (C20 to C34) and their derived compounds are often extracted from suberin tissues $(6,68)$. Peridermal wax composition has been reported for cork oak (Quercus suber) (63) and potato (57). KCSs are encoded by a multigene family with 21 members in Arabidopsis thaliana (30) and, recently, several reports have shown the involvement of KCS family members in root suberin biosynthesis in $A$. thaliana $(19,68)$ and cuticular wax formation in tomato fruit $(39,71)$. A 
recent work showed that silencing of the KCS member StKCS6 in potato periderm leads to reduced chain lengths of suberin and wax compounds and increased peridermal transpiration (58).

The role of CYP86A1 (CYP86A33 ortholog) in the biosynthesis of suberin has recently been confirmed in the primary root of $A$. thaliana knockout mutants $(26,38)$. Moreover, in other recent work with potato, Serra et al. (59) showed that CYP86A33targeted gene silencing in tubers alters suberin composition, distorts suberin lamellae, and impairs the function of the periderm as a water barrier. It has been previously reported in bean (Phaseolus vulgaris L.) and rice plants (Oryza sativa L.) that infection with virulent isolates of $R$. solani activates many defenserelated genes and results in the production of pathogenesis-related proteins and lignifications and suberization processes (14,24, $38,65,73)$. Friend et al. (22) showed increases in the activity of phenylalanine ammonia-lyase and the level of chlorogenic acid, accompanied by the accumulation of a lignin-like polymer on potato tuber disks in response to inoculation with Phytophthora infestans. In the interaction of potato tubers with $V$. dahliae, hypersensitive browning and suberization are characteristic of the initial events in resistance, rather than the production and accumulation of phytoalexins (70).

We also showed that $R$. solani induces higher expression of $P O P \_A$, which encodes a wound-induced and suberizationassociated anionic peroxidase (53) $48 \mathrm{~h}$ after inoculation. Barel and Ginzberg (4) showed increased expression of $P O P \_A$ in the tuber skin during skin set compared with tuber flesh, suggesting its role in periderm formation.

To summarize, in the present study, we demonstrate that $R$. solani is the pathogen responsible for the formation of potato tuber dark spots during tuber storage. We show that standard storage conditions for tubers that are harvested before skin set ("baby potatoes") strongly promote tuber infection by $R$. solani. Our data indicate that the formation of dark spot symptoms in response to $R$. solani is associated with accumulation and oversuberization of the tuber cells exposed to the pathogen. It is likely that this response prevents pathogen penetration deep inside the tuber. Further investigations are required to understand the mechanism underlying the suberization response to pathogens.

\section{LITERATURE CITED}

1. Banville, G. J. 1978. Studies on the Rhizoctonia disease of potatoes. Am. J. Potato Res. 55:56.

2. Banville, G. J. 1989. Yield losses and damage to potato plants caused by Rhizoctonia solani Kuhn. Am. J. Potato Res. 66:821-834.

3. Banville, G. J., Carling, D. E., and Otrysko, B. E. 1996. Rhizoctonia disease on potato. Pages 321-330 in: Rhizoctonia Species: Molecular Biology, Ecology, Pathology and Disease Control. S. B. Sneh, S. JabajiHare, and G. Dijst eds. Kluwer Academic Publishers, Dordrecht, The Netherlands.

4. Barel, G., and Ginzberg, I. 2008. Potato skin proteome is enriched with plant defence components. J. Exp. Bot. 59:3347-3375.

5. Bernards, M. A. 2002. Demystifying suberin. Can. J. Bot. 80:227-240.

6. Bernards, M. A., and Razem, F. A. 2001. The poly (phenolic) domain of potato suberin: A non-lignin cell wall bio-polymer. Phytochemistry 57:1115-1122.

7. Borchert, R. 1978. Time course and spatial distribution of phenylalanine ammonia-lyase and peroxidase activity in wounded potato tuber tissue. Plant Physiol. 62:789-793.

8. Borchert, R., and Decedue, C. J. 1978. Simultaneous separation of acidic and basic isoperoxidases in wounded potato tissue by acrylamide gel electrophoresis. Plant Physiol. 62:794-797.

9. Bruns, T. D., White, T. J., and Taylor, J. W. 1991. Fungal molecular systematics. Annu. Rev. Ecol. Syst. 22:525-564.

10. Campanella, J. J., Bitincka, L., and Smalley, J. 2003. MatGAT: An application that generates similarity/identity matrices using protein or DNA sequences. BMC Bioinf. 4:29-32.

11. Carling, D. E., Kuninaga, S., and Brainard, K. A. 2002. Hyphal anastomosis reactions, rDNA-internal transcribed spacer sequences, and virulence levels among subsets of Rhizoctonia solani anastomosis group-2 (AG-2) and AG-BI. Phytopathology 92:43-50.
12. Carling, D. E., Leiner, R. H., and Westphale, P. C. 1989. Symptoms, signs and yield reduction associated with Rhizoctonia disease of potato induced by tuberborne inoculum of Rhizoctonia solani AG-3. Am. J. Potato Res. 66:693-701.

13. Cassagne, C., Lessire, R., Bessoule, J. J., Moreau, P., Creach, A., Schneider, F., and Sturbois, B. 1994. Biosynthesis of very long chain fatty acids in higher plants. Progr. Lipid Res. 33:55-69.

14. Deborah, S. D., Palaniswami, A., Vidhyasekaran, P., and Velazhahan, R. 2001. Time-course study of the induction of defense enzymes, phenolics and lignin in rice in response to infection by pathogen and non-pathogen. J. Plant Dis. Prot. 108:204-216.

15. Du, Z. Y., Chen, J. S., and Hiruki, C. 2006. Optimization and application of a multiplex RT-PCR system for simultaneous detection of five potato viruses using 18S rRNA as an internal control. Plant Dis. 90:185-189.

16. Espelie, K. E., Franceschi, V. R., and Kolattukudy, P. E. 1986. Immunocytochemical localization and time course of appearance of an anionic peroxidase associated with suberization in wound-healing potato tuber tissue. Am. Soc. Plant Biol. 81:487-492.

17. Espelie, K. E., and Kolattukudy, P. E. 1985. Purification and characterization of an abscisic acid-inducible anionic peroxidase associated with suberization in potato (Solanum tuberosum). Arch. Biochem. Biophys. 240:539-545.

18. Felsenstein, J. 1989. PHYLIP: Phylogeny inference package (version 3.2). Cladistics 5:164-166.

19. Franke, R., Briesen, I., Wojciechowski, T., Faust, A., Yephremov, A., Nawrath, C., and Schreiber, L. 2005. Apoplastic polyesters in Arabidopsis surface tissues - a typical suberin and a particular cutin. Phytochemistry 66:2643-2658

20. Franke, R., and Schreiber, L. 2007. Suberin-a biopolyester forming apoplastic plant interfaces. Curr. Opin. Plant Biol. 10:252-259.

21. Freeman, S., Minz, D., Jurkevitch, E., Maymon, M., and Shabi, E. 2000. Molecular analyses of Colletotrichum species from almond and other fruits. Phytopathology 90:608-614.

22. Friend, J., Reynolds, S. B., and Aveyard, M. A. 1973. Phenylalanine ammonia lyase, chlorogenic acid and lignin in potato tuber tissue inoculated with Phytophthora infestans. Physiol. Plant Pathol. 3:495-507.

23. Gerlach, D. 1984. Botanische Mikrotechnik: Eine Einführung. Georg Thieme, Stuttgart, Germany.

24. Guillon, C., St-Arnaud, M., Hamel, C., and Jabaji-Hare, S. H. 2002. Differential and systemic alteration of defence-related gene transcript levels in mycorrhizal bean plants infected with Rhizoctonia solani. Botany 80:305-315.

25. Hammerschmidt, R. 1985. Determination of natural and wound-induced potato tuber suberin phenolics by thioglycolic acid derivatization and cupric oxide oxidation. Potato Res. 28:123-127.

26. Hofer, R., Briesen, I., Beck, M., Pinot, F., Schreiber, L., and Franke, R. 2008. The Arabidopsis cytochrome P450 CYP86A1 encodes a fatty acid $\omega$-hydroxylase involved in suberin monomer biosynthesis. J. Exp. Bot. 59:2347-2360.

27. James, W. C., and McKenzie, A. R. 1972. The effect of tuber-borne sclerotia of Rhizoctonia solani Kühn on the potato crop. Am. J. Potato Res. 49:296-301.

28. Johansen, D. E. 1940. Plant Microtechniques. McGraw-Hill Book Company, Inc., New York.

29. Johnk, J. S., Jones, R. K., Shew, H. D., and Carling, D. E. 1993. Characterization of populations of Rhizoctonia solani AG-3 from potato and tobacco. Phytopathology 83:854-858.

30. Joube's, J., Raffaele, S., Bourdenx, B., Garcia, C., Laroche-Traineau, J., Moreau, P., Domergue, F., and Lessire, R. 2008. The VLCFA elongase gene family in Arabidopsis thaliana: Phylogenetic analysis, 3D modelling and expression profiling. Plant Mol. Biol. 67:547-566.

31. Kimura, M. 1980. A simple method for estimating evolutionary rates of base substitutions through comparative studies of nucleotide sequences. J. Mol. Evol. 16:111-120.

32. Knowles, N. R., Iritani, W. M., Weiler, L. D., and Gross, D. C. 1982. Susceptibility of potatoes to bacterial rot and weight loss as a function of wound-healing interval and temperature. Am. J. Potato Res. 59:515-522.

33. Kolattukudy, P. E. 1984. Biochemistry and function of cutin and suberin. Can. J. Bot. 62:2918-2933.

34. Kolattukudy, P. E. 1987. Lipid-derived defensive polymers and waxes and their role in plant-microbe interaction. Pages 291-314 in: The Biochemistry of Plants: A Comprehensive Treatise. P. K. Stumpf, ed. Academic Press Inc., Orlando, FL.

35. Kuninaga, S., Carling, D. E., Takeuchi, T., and Yokosawa, R. 2000. Comparison of rDNA-ITS sequences between potato and tobacco strains in Rhizoctonia solani AG-3. J. Gen. Plant Pathol. 66:2-11.

36. Kuninaga, S., Natsuaki, T., Takeuchi, T., and Yokosawa, R. 1997. Sequence variation of the rDNA ITS regions within and between anastomosis groups in Rhizoctonia solani. Curr. Genet. 32:237-243.

37. Kuramae, E. E., Buzeto, A. L., Ciampi, M. B., and Souza, N. L. 2003. 
Identification of Rhizoctonia solani AG 1-IB in lettuce, AG 4 HG-I in tomato and melon, and AG 4 HG-III in broccoli and spinach, in Brazil. Eur. J. Plant Pathol. 109:391-395.

38. Lee, J., Bricker, T. M., Lefevre, M., Pinson, S. R. M., Oard, J. H., and Usda, A. R. S. 2006. Proteomic and genetic approaches to identifying defence-related proteins in rice challenged with the fungal pathogen Rhizoctonia solani. Mol. Plant Pathol. 7:405-416.

39. Leide, J., Hildebrandt, U., Reussing, K., Riederer, M., and Vogg, G. 2007. The developmental pattern of tomato fruit wax accumulation and its impact on cuticular transpiration barrier properties: Effects of a deficiency in a beta-ketoacyl-coenzyme A synthase (LeCER6). Plant Physiol. 144:1667-1679.

40. Liu, Z. L., Sinclair, J. B., and Chen, W. 1992. Genetic diversity of Rhizoctonia solani anastomosis group 2. Phytopathology 82:778-787.

41. Lulai, E. C. 2005. Non-wound-induced suberization of tuber parenchyma cells: A physiological response to the wilt disease pathogen Verticillium dahliae. Am. J. Potato Res. 82:433-440.

42. Lulai, E. C., and Corsini, D. L. 1998. Differential deposition of suberin phenolic and aliphatic domains and their roles in resistance to infection during potato tuber (Solanum tuberosum L.) wound-healing. Physiol. Mol. Plant Pathol. 53:209-222.

43. Lulai, E. C., and Orr, P. H. 1994. Techniques for detecting and measuring developmental and maturational changes in tuber native periderm. Am. J. Potato Res. 71:489-505.

44. Lulai, E. C., Weiland, J. J., Suttle, J. C., Sabba, R. P., and Bussan, A. J. 2006. Pink eye is an unusual periderm disorder characterized by aberrant suberization: A cytological analysis. Am. J. Potato Res. 83:409-421.

45. Lyon, G. D. 1989. The biochemical basis of resistance of potatoes to soft rot Erwinia spp.-a review. Plant Pathol. 38:313-339.

46. Meisel, L., Fonseca, B., González, S., Baeza-Yates, R., Cambiazo, V., Campos, R., Gonzalez, M., Orellana, A., Retamales, J., and Silva, H. 2005. A rapid and efficient method for purifying high quality total RNA from peaches (Prunus persica) for functional genomics analyses. Biol. Res. 38:83-88.

47. Moire, L., Schmutz, A., Buchala, A., Yan, B., Stark, R. E., and Ryser, U. 1999. Glycerol is a suberin monomer. New experimental evidence for an old hypothesis. Plant Physiol. 119:1137-1146.

48. Nicholas, K. B., Nicholas, H. B., and Deerfield, D. W. 1997. GeneDoc: Analysis and visualization of genetic variation. EMBnet NEWS 4:14.

49. Page, R. D. M. 1996. Tree View: An application to display phylogenetic trees on personal computers. Bioinformatics 12:357.

50. Parmeter, J. R, Jr., and Whitney, H. S. 1970. Taxonomy and nomenclature of the imperfect state. Pages 7-19 in: Rhizoctonia solani, Biology and Pathology. J. R. Parmeter, Jr., ed. University of California Press, Berkeley

51. Platt, H. W., Canale, F., and Gimenez, G. 1993. Effects of tuber-borne inoculum of Rhizoctonia solani and fungicidal seed potato treatment on plant growth and Rhizoctonia disease in Canada and Uruguay. Am. J. Potato Res. 70:553-559.

52. Reeve, R. M., Hautala, E., and Weaver, M. L. 1969. Anatomy and compositional variation within potatoes. Am. J. Potato Res. 46:361-373.

53. Roberts, E., Kutchan, T., and Kolattukudy, P. E. 1988. Cloning and sequencing of cDNA for a highly anionic peroxidase from potato and the induction of its mRNA in suberizing potato tubers and tomato fruits. Plant Mol. Biol. 11:15-26.

54. Rodriguez, R. J. 1993. Polyphosphate present in DNA preparations from filamentous fungal species of Colletotrichum inhibits restriction endonucleases and other enzymes. Anal. Biochem. 209:291-297.

55. Ruzin, S. E. 1999. Plant Microtechnique and Microscopy. Oxford University Press, New York.

56. Scholte, K. 1989. Effects of soil-borne Rhizoctonia solani Kühn on yield and quality of ten potato cultivars. Potato Res. 32:367-376.

57. Schreiber, L., Franke, R., and Hartmann, K. 2005. Wax and suberin development of native and wound periderm of potato (Solanum tuberosum L.) and its relation to peridermal transpiration. Planta 220:520-530.
58. Serra, O., Soler, M., Hohn, C., Franke, R., Schreiber, L., Prat, S., Molinas, M., and Figueras, M. 2009. Silencing of StKCS6 in potato periderm leads to reduced chain lengths of suberin and wax compounds and increased peridermal transpiration. J. Exp. Bot. 60:697-707.

59. Serra, O., Soler, M., Hohn, C., Sauveplane, V., Pinot, F., Franke, R., Schreiber, L., Prat, S., Molinas, M., and Figueras, M. 2009. CYP86A33targeted gene silencing in potato tuber alters suberin composition, distorts suberin lamellae, and impairs the periderm's water barrier function. Plant Physiol. 149:1050-1060.

60. Sharon, M., Freeman, S., Kuninaga, S., and Sneh, B. 2007. Genetic diversity, anastomosis groups and virulence of Rhizoctonia spp. from strawberry. Eur. J. Plant Pathol. 117:247-265.

61. Sharon, M., Kuninaga, S., Hyakumachi, M., and Sneh, B. 2006. The advancing identification and classification of Rhizoctonia spp. using molecular and biotechnological methods compared with the classical anastomosis grouping. Mycoscience 47:299-316.

62. Sherwood, R. T. 1970. Physiology of Rhizoctonia solani. Pages 69-92 in: Rhizoctonia solani, Biology and Pathology. J. R. Parmeter, Jr., ed. University of California Press, Berkeley.

63. Silva, S. P., Sabino, M. A., Fernandes, E. M., Correlo, V. M., Boesel, L. F., and Reis, R. L. 2005. Cork: Properties, capabilities and applications. Int. Mat. Rev. 50:345-365.

64. Sneh, B., Burpee, L., and Ogoshi, A. 1991. Anastomosis groups of binucleate Rhizoctonia spp. Pages 133-139 in: Rhizoctonia Species: Molecular Biology, Ecology, Pathology and Disease Control. S. B. Sneh, S. Jabaji-Hare, and G. Dijst, eds. Kluwer Academic Publishers, Dordrecht, The Netherlands

65. Stockwell, V., and Hanchey, P. 1987. Lignification of lesion borders in Rhizoctonia-infected bean hypocotyls. Phytopathology 77:589-593.

66. Suneja, S. K., Nagi, M. N., Cook, L., and Cinti, D. L. 1991. Decreased long-chain fatty acyl CoA elongation activity in quaking and jimpy mouse brain: Deficiency in one enzyme or multiple enzyme activities. J. Neurochem. 57:140-146.

67. Thomas, R., Fang, X., Ranathunge, K., Anderson, T. R., Peterson, C. A., and Bernards, M. A. 2007. Soybean root suberin: Anatomical distribution, chemical composition, and relationship to partial resistance to Phytophthora sojae. Plant Physiol. 144:299.

68. Todd, J., Post-Beittenmiller, D., and Jaworski, J. G. 1999. KCS1 encodes a fatty acid elongase 3-ketoacyl-CoA synthase affecting wax biosynthesis in Arabidopsis thaliana. Plant J. 17:119-130.

69. Tsror (Lahkim), L. 2010. Biology, epidemiology and management of Rhizoctonia solani on potato. J. Phytopathol. 158:649-658.

70. Vaughn, S. F., and Lulai, E. C. 1991. The involvement of mechanical barriers in the resistance response of a field-resistant and a fieldsusceptible potato cultivar to Verticillium dahliae. Physiol. Mol. Plant Pathol. 38:455-465.

71. Vogg, G., Fischer, S., Leide, J., Emmanuel, E., Jetter, R., Levy, A. A., and Riederer, M. 2004. Tomato fruit cuticular waxes and their effects on transpiration barrier properties: Functional characterization of a mutant deficient in a very-long-chain fatty acid \{beta\}-ketoacyl-CoA synthase. J. Exp. Bot. 55:1401-1410.

72. Weinhold, A. R., Bowman, T., and Hall, D. H. 1982. Rhizoctonia disease of potato: Effect on yield and control by seed tuber treatment. Plant Dis. 66:815-818

73. Wen, K., Seguin, P., St.-Arnaud, M., and Jabaji-Hare, S. 2005. Real-time quantitative RT-PCR of defense-associated gene transcripts of Rhizoctonia solani-infected bean seedlings in response to inoculation with a nonpathogenic binucleate Rhizoctonia isolate. Phytopathology 95:345353.

74. White, T. J., Bruns, T. D., Lee, S., and Taylor, J. W. 1990. Amplification and direct sequencing of fungal ribosomal RNA genes for phylogenetics. Pages 315-322 in: PCR Protocols: A Guide to Methods and Applications. M. Gelfand, J. I. Sninsky, and T. J. White, eds. Academic Press, New York. 